\title{
The Japanese alga Polysiphonia morrowii (Rhodomelaceae, Rhodophyta) on the South Atlantic Ocean: first report of an invasive macroalga inhabiting oyster reefs
}

\author{
M. Emilia Croce $\cdot$ Elisa R. Parodi
}

Received: 21 July 2013/Revised: 31 January 2014/Accepted: 4 February 2014/Published online: 14 February 2014

(C) Springer-Verlag Berlin Heidelberg and AWI 2014

\begin{abstract}
Conspicuous tufts of the filamentous algae Polysiphonia Greville inhabit the reefs of Crassostrea gigas on the Atlantic Patagonian coast. The population was recorded for the first time in 1994 and identified as $P$. argentinica. This study exhaustively investigated the morphology and reproduction of specimens and the seasonality of the population. The results revealed the identity of the specimens as the invasive Japanese macroalga $\mathrm{Po}$ lysiphonia morrowii Harvey, on the basis of several striking features: the setaceous and tufted thalli, the corymbose growing apices, the endogenous axillary branches, the urceolate cystocarps and the sharply pointed branches. Sexual reproduction was evidenced; however, fertile male gametophytes were absent in the samples. The population was found almost all year round, but its abundance became higher in autumn and winter. The present study constitutes the first record of this invasive macroalga on the South Atlantic Ocean; the fourth record of an exotic macroalgal species on the Atlantic Patagonian coast; and the first record of an invasive species related to the establishment of C. gigas in Atlantic Patagonia.
\end{abstract}

Communicated by F. Weinberger.

M. E. Croce · E. R. Parodi $(\bowtie)$

Laboratorio de Ficología Aplicada, Instituto Argentino de Oceanografía (IADO), CONICET-Bahía Blanca, Camino Carrindanga 7,5 km, B8000FTN Bahía Blanca, Argentina e-mail: elipapers@criba.edu.ar

\section{E. R. Parodi}

Laboratorio de Ecología Acuática, Departamento de Biología, Bioquímica y Farmacia, Universidad Nacional del Sur, San Juan 670, B8000ICN Bahía Blanca, Argentina
Keywords Atlantic Patagonia - Crassostrea gigas . Endogenous axillary branches · Invasive macroalgae · Oyster reefs · Polysiphonia morrowii

\section{Introduction}

Polysiphonia Greville is a widespread genus of red macroalgae of which numerous species have been recognized (Meñez 1964; Hollenberg and Norris 1977; Womerseley 1979; Kapraun and Rueness 1983; Yoon 1986). Members of this genus are characterized by filamentous and often delicate thallus that grows within intertidal and subtidal habitats, ranging from turbid estuaries to clear waters (Adams 1991). This algal group has a long nomenclatural history (e.g., Kim et al. 2000; Kim 2003). Molecular tools have helped understanding the phylogeny of related species (Choi et al. 2001; McIvor et al. 2001; Stuercke and Freshwater 2008), while morphological studies contributed to the comprehension of phenotypic variability and the relation of distant populations (Curiel et al. 2002; Kim et al. 2004; Kim and Abbot 2006; Stuercke and Freshwater 2010).

Some Polysiphonia species are responsible for algal epiphytism and blooms that affect the natural communities (Lobban and Baxter 1983; Kapraun and Searles 1990); therefore, many studies have been focused on ecological and physiological aspects of this genus (Fralick and Mathieson 1975; Lee and Lee 1991; Lining and Garbary 1992). There is evidence that filamentous invasive macroalgae such as Polysiphonia are able to produce changes in the biodiversity of native ecosystems, providing substrate for the settlement of protozoa, colonial diatoms and early stages of macroalgae, hence increasing the complexity of the ecosystems that they invade (Thomsen et al. 2006). 
Several species of Polysiphonia have been found in nonnative habitats where introductions are supposed to be the result of aquaculture initiatives (Maggs and Stegenga 1999; Haydar and Wolff 2011; Geoffroy et al. 2012). The most invasive species include $P$. morrowii Harvey, P. brodiei (Dillwyn) Sprengel, P. breviarticulata (C. Agardh) Zanardini and $P$. harveyi J.W. Bailey (currently considered a synonym for Neosiphonia harveyi (J.W. Bailey) M.S. Kim, H.G. Choi, Guiry and G.W. Saunders) (Gardner 1927; Kapraun and Searles 1990; Eno 1996; McIvor et al. 2001; Sliwa et al. 2009). As noticed by several authors, the possible vectors of their introductions include ballast water, vessel fouling and transport of oysters, especially of Crassostrea gigas (Thunberg, 1793) (Kapraun and Searles 1990; Curiel et al. 2002; Kim et al. 2004; Geoffroy et al. 2012). Oyster transfer for commercial purposes is considered the most important vector of macroalgae introductions (Gruet 1976; Verlaque 1981; Stegenga et al. 1997; Mineur et al. 2007).

In 1994, the presence of $C$. gigas was detected at the north Patagonian Atlantic coast of Argentina, and later in 2001, a monitoring campaign of the established reefs was started (Borges et al. 2005, Borges 2006). According to the literature, these reefs comprise the only established populations of $C$. gigas currently known in Argentina, which are inhabited by conspicuous macroalgal assemblages (Borges et al. 2005; Borges 2006; Croce and Parodi 2012). The local information suggests that oysters were transplanted from Chile in 1982 for culture purposes (Orensanz et al. 2002).

Several individuals of a red seaweed were found in Anegada Bay for the first time in 1994, which were identified as $P$. argentinica W.R. Taylor (currently considered a synonym of $N$. harveyi) (Borges et al. 2005). From 2001 to 2005, ecological surveys were carried out in the region, and the red seaweed was found again as part of the fouling communities on artificial substrates and also in epibiosis with $C$. gigas (Borges et al. 2005). Later on, the species was recognized as Polysiphonia abscissa J.D. Hooker and Harvey during an ecological survey of the macroalgal community inhabiting the reefs (Croce and Parodi 2012). Currently, this Polysiphonia population dominates the macroalgal community and forms almost monospecific stands in this habitat (Croce and Parodi 2012). The particular location of the population in the oyster reefs led to us to check the identity of this macroalga. The aim of the present study was to analyze the vegetative and reproductive morphology of Polysiphonia specimens from the oyster reefs located in Anegada Bay and to evaluate the seasonality of the population. In addition, as only a few Polysiphonia species from the South Atlantic Ocean have been studied and detailed descriptions are scarce (Lazo 1982; Boraso et al. 2004), our results contribute to the understanding of distribution and morphology of Polysiphonia populations in this region of the world.

\section{Methods}

Sampling site

The survey was carried out in the oyster reefs located in Anegada Bay $\left(40^{\circ} 25^{\prime} \mathrm{S} ; 62^{\circ} 25^{\prime} \mathrm{W}\right)$ at the north Patagonian Atlantic coast of Argentina (Fig. 1). The coast has a semidiurnal tidal regime and is constituted by tidal flats where Crassostrea gigas has established large populations of approximately $127.982 \mathrm{~m}^{2}$ (Spalleti 1980; Borges 2006).

Field methods

Surveying of specimens was carried out during 2009, 2010 and 2011 in the pools formed on C. gigas intertidal reefs. Collection of thalli for identification and morphological studies was done from March to November of consecutive years.

In order to estimate the seasonal changes in abundance of this species, biomass samples were obtained in four sampling months, representative of each season, during 1 year. A total of 72 pools (18 per season) were randomly selected along transects haphazardly located in the intertidal and orthogonal to the shoreline. Polysiphonia biomass was harvested inside the pools using quadrates of $0.25 \mathrm{~m}^{2}$ to estimate relative biomass.

All biological material was transferred to the laboratory in plastic bags, inside cold boxes.

Laboratory methods

Observations on the external appearance and morphology were made on fresh specimens with a stereoscopic microscope Wild Heerbrugg. Cross sections of thalli were examined with an inverted microscope Nikon Eclipse TE (Nikon, Tokyo, Japan), and photographs were taken with a digital camera Nikon FDX 35 (Nikon, Tokyo, Japan). Selected portions of specimens were preserved in glutaraldehyde-seawater $2.5 \%$ at $5{ }^{\circ} \mathrm{C}$ in cacodylate buffer, mounted on slides and dehydrated for further observations with a Leo Evo 40 SEM (Cambridge, UK). Morphometric measurements were taken using a micrometric ocular and/ or obtained from photographs using the UTHSCSA Image Tool version 3.00 software (developed by University of Texas Health Science Center of San Antonio, Texas, ftp:// maxrad6.uthscsa.edu, 2011). Identification of the specimens was carried out, and their morphology was compared with other descriptions. The material identified was 


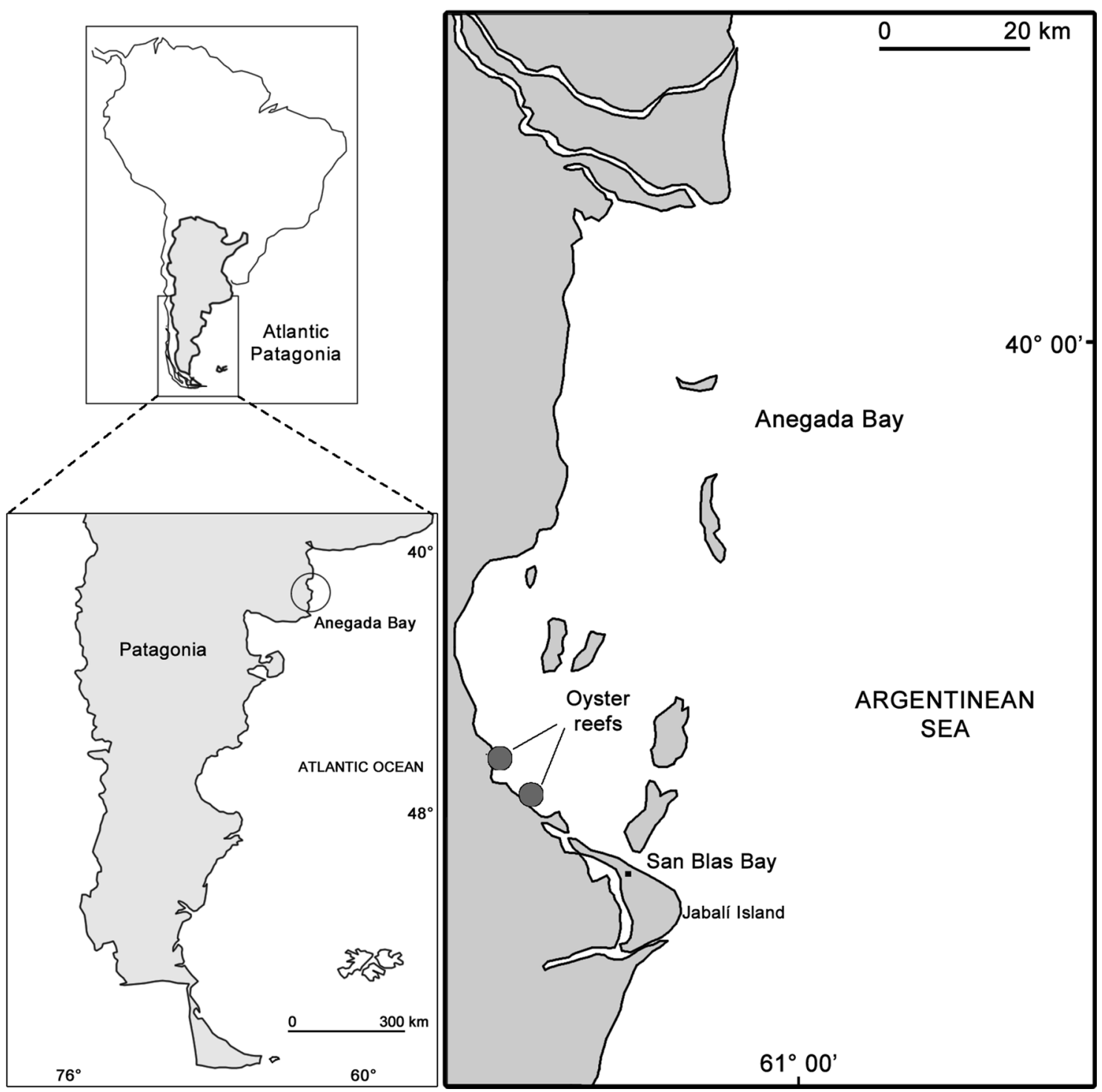

Fig. 1 Geographical location of the oyster reefs in the Southwest Atlantic coast, where Polysiphonia specimens were collected

deposited in the Herbarium of Universidad Nacional del Sur, Argentina: BBB (Croce 344-Croce 347) and BBB (Croce 020F-Croce 025F).

Polysiphonia biomass was rinsed with seawater, drained for $2 \mathrm{~h}$ on blotting paper, then weighted and dried in an oven at $60{ }^{\circ} \mathrm{C}$. An average of relative wet weight (WW) and dry weight (DW) was obtained for each season, and the differences in abundance were tested using Kruskal-Wallis analysis and Fisher's pairwise comparisons with the $\mathrm{R}$ software (R Development Core Team 2012).

\section{Results}

Polysiphonia grew densely and formed extensive patches in the oyster reefs. The thalli were strongly attached to the shells of the exotic oyster C. gigas and less frequently to the mussel Brachidontes rodriguezii d'Orbigny.

On the basis of the morphological characteristics observed, the specimens were identified as Polysiphonia morrowii. Thalli were long and slender, up to $26 \mathrm{~cm}$, and formed dense tufts (Fig. 2a, b). The color of thalli varied; well-developed and "healthy" specimens were dark red (Fig. 2d), while epiphytized thalli were yellowish or brownish (Fig. 2c). The texture of thalli was setaceous.

Thalli were composed of a basal portion of prostrate axes, highly entangled and strongly attached to the substratum from which erect axes arose. The erect part of the thallus was more developed than the prostrate part. The basal parts of erect axes were scarcely branched and had short determinate branches, sometimes recurved, while the middle and distal parts were profusely branched forming 

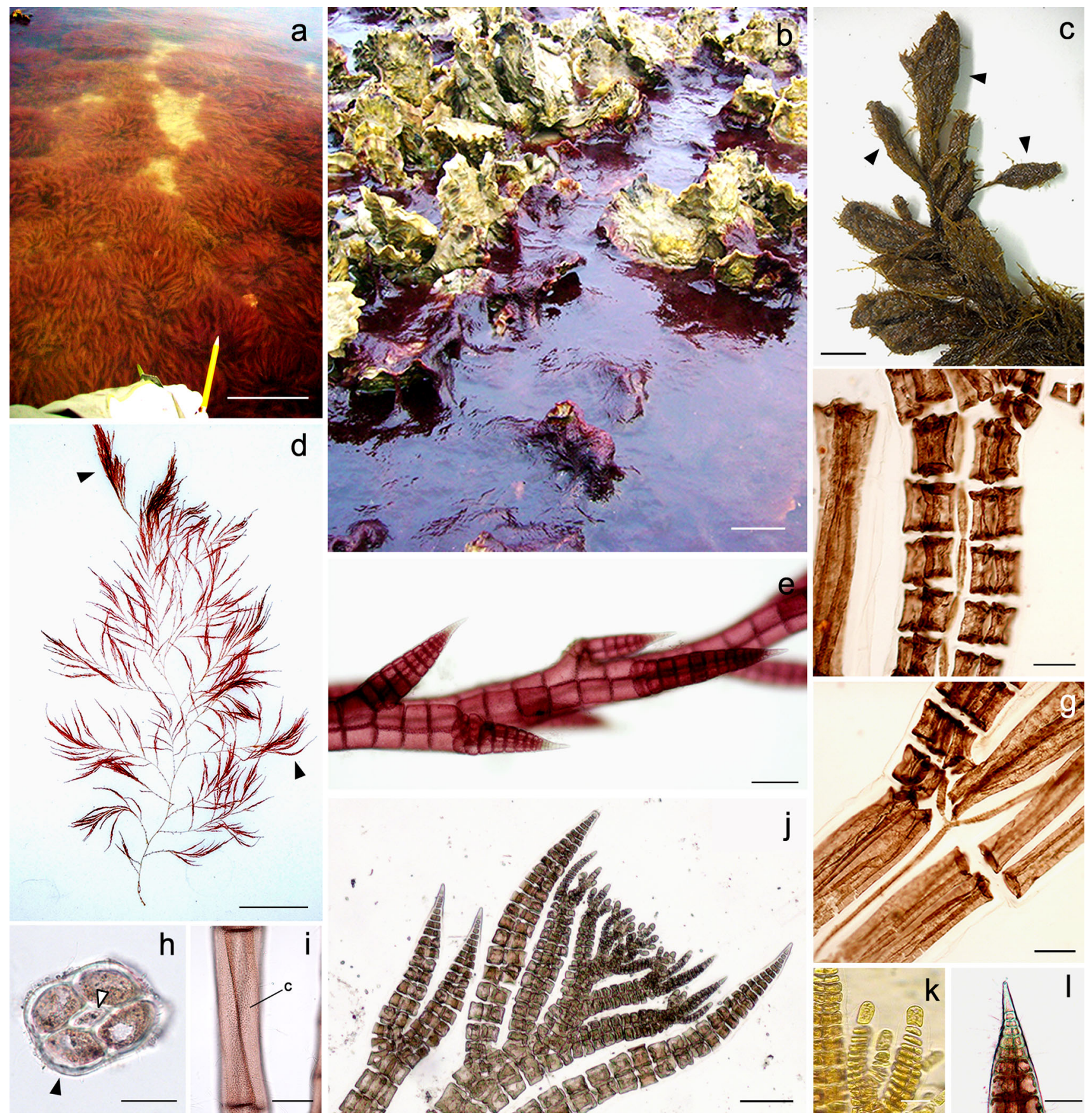

Fig. 2 Polysiphonia morrowii. Habitat and vegetative morphology. a General view of an intertidal population; b specimens inhabiting the intertidal pools between Crassotrea gigas individuals; c general aspect of an epiphytized thallus; arrowheads denote clumps of sediment; d branching pattern; arrowheads denote fascicles; e detail of branching, denoting the spiral pattern and the frequency of branches; f prostrate axes showing central and pericentral cells; $\mathbf{g}$ erect axes showing central and pericentral cells; $\mathbf{h}$ cross section of

conspicuous fascicles (Fig. 2d). Branching was alternate in a spiral pattern every 2-6 segments (Fig. 2e).

Prostrate and erect axes were composed of a central cell surrounded by four pericentral cells without cortication erect axes showing the central cell (white arrowhead) surrounded by four pericentral cells (black arrowhead); i detail of a segment presenting the spiral arrangement of pericentral cells, $C$ chloroplasts; $\mathbf{j}$ corymbose growing apices; $\mathbf{k}$ detail of rounded apical cells at growing apices; $\mathbf{l}$ detail of a spinose apical cell at determinate branches. Scale bars $\mathbf{a}=30 \mathrm{~cm} ; \mathbf{b}=4 \mathrm{~cm} ; \mathbf{c}$ and $\mathbf{d}=1 \mathrm{~cm}$; $\mathbf{e}=125 \mu \mathrm{m} ; \mathbf{f}, \mathbf{g}$ and $\mathbf{i}=100 \mu \mathrm{m} ; \mathbf{h}$ and $\mathbf{j}=50 \mu \mathrm{m} ; \mathbf{k}$ and $\mathbf{l}=25 \mu \mathrm{m}$

(Fig. 2f-h). The chloroplasts were small disks, densely packed and form a network (Fig. 2i).

The thickness of axes was 52-118 $\mu \mathrm{m}$ and 46-223 $\mu \mathrm{m}$ in prostrate and erect axes, respectively. The length/width 


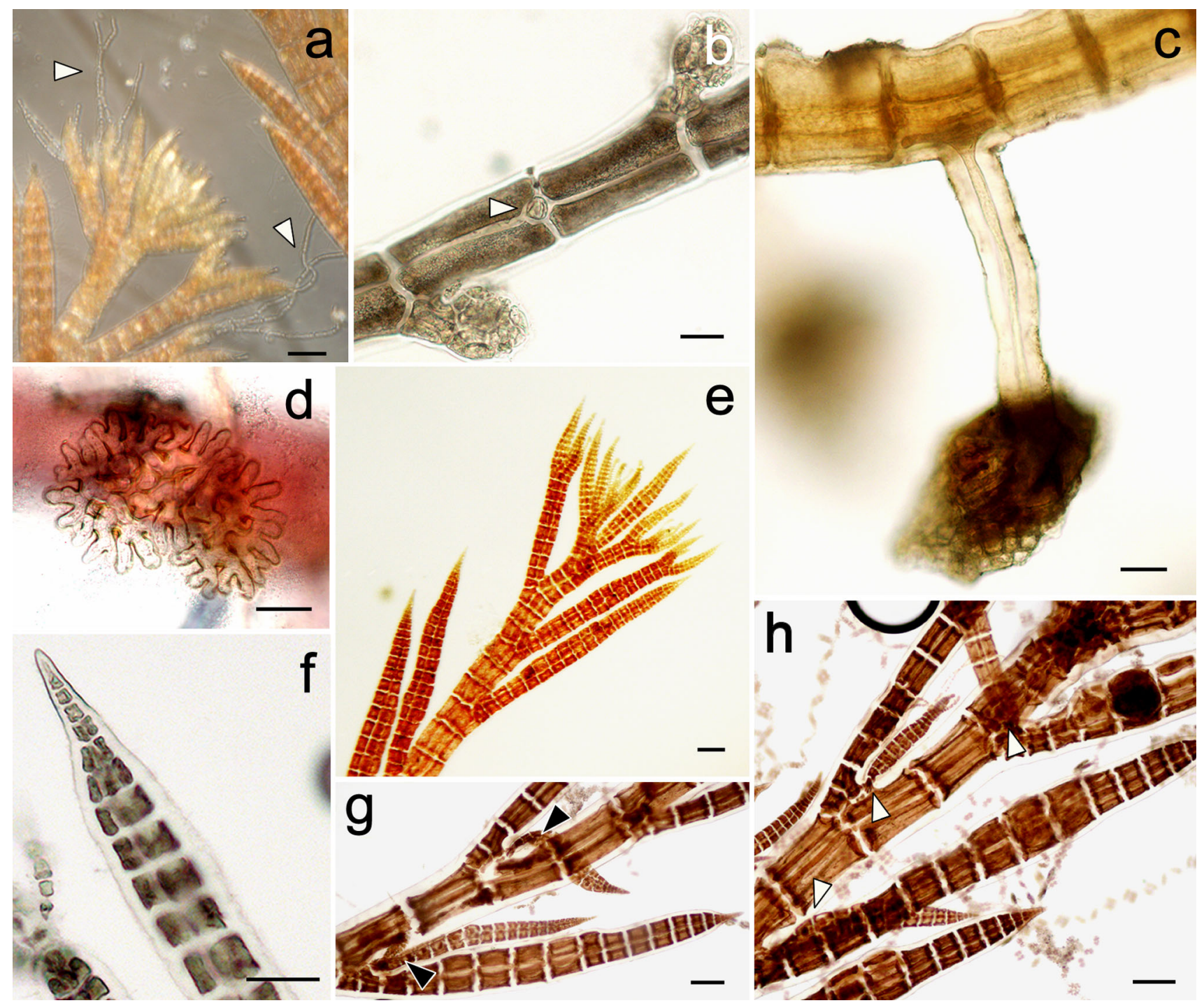

Fig. 3 Polysiphonia morrowii. Vegetative morphology. a Trichoblast presenting several furcations (arrowheads); b conspicuous scar cell (arrowhead); $\mathbf{c}$ rhizoid in open connection with the pericentral cell; d detail of highly digitated attachment disk of rhizoids; e sharply

$(\mathrm{L} / \mathrm{W})$ ratio of segments was between 0.8 and 11 . The diameter of the central cell varied from 19 to $38 \mu \mathrm{m}$. Pericentral cells were longer and wider in erect axes than in prostrate axes. Pericentral cells from prostrate axes measured $21.53-96.25 \mu \mathrm{m}$ in length and 16.76-63.27 $\mu \mathrm{m}$ in width. In erect axes, pericentral cells measured 45.15-947.05 $\mu \mathrm{m}$ in length and 23.49-103.57 $\mu \mathrm{m}$ in width.

Growing apices displayed a corymbose pattern (Fig. 2j). Apical cells were conspicuous and rounded in the growing apices (Fig. 2k), while spinose in determinate branches (Fig. 2l). Apical division was slightly oblique.

Trichoblasts were scarce, but were located near the apices of erect axes, when present. They were colorless, up to three times furcated and deciduous (Fig. 3a). Scar cells pointed shape of ultimate branches; $\mathbf{f}$ detail of sharply pointed branches; $\mathbf{g}, \mathbf{h}$ endogenous axillary branches (arrowheads). Scale bars $50 \mu \mathrm{m}$

were scarce, but were conspicuous with no evident arrangement, when present (Fig. 3b). Branches were not related to trichoblasts.

Prostrate axes were attached to the substratum by several unicellular rhizoids. Rhizoids were little-pigmented and originated from the center or the proximal end of a pericentral cell remaining in open connection with them (Fig. 3c). The shape of rhizoids was variable, some were short with a highly digitated attachment disk (Fig. 3d), and others were long and narrow, ending in a rounded tip. The length of rhizoids varied from 170 to $1,000 \mu \mathrm{m}$ and width varied from 14 to $86 \mu \mathrm{m}$.

The shape of ultimate branches was sharply pointed (Fig. 3e, f). A few specimens presented lateral adventitious 


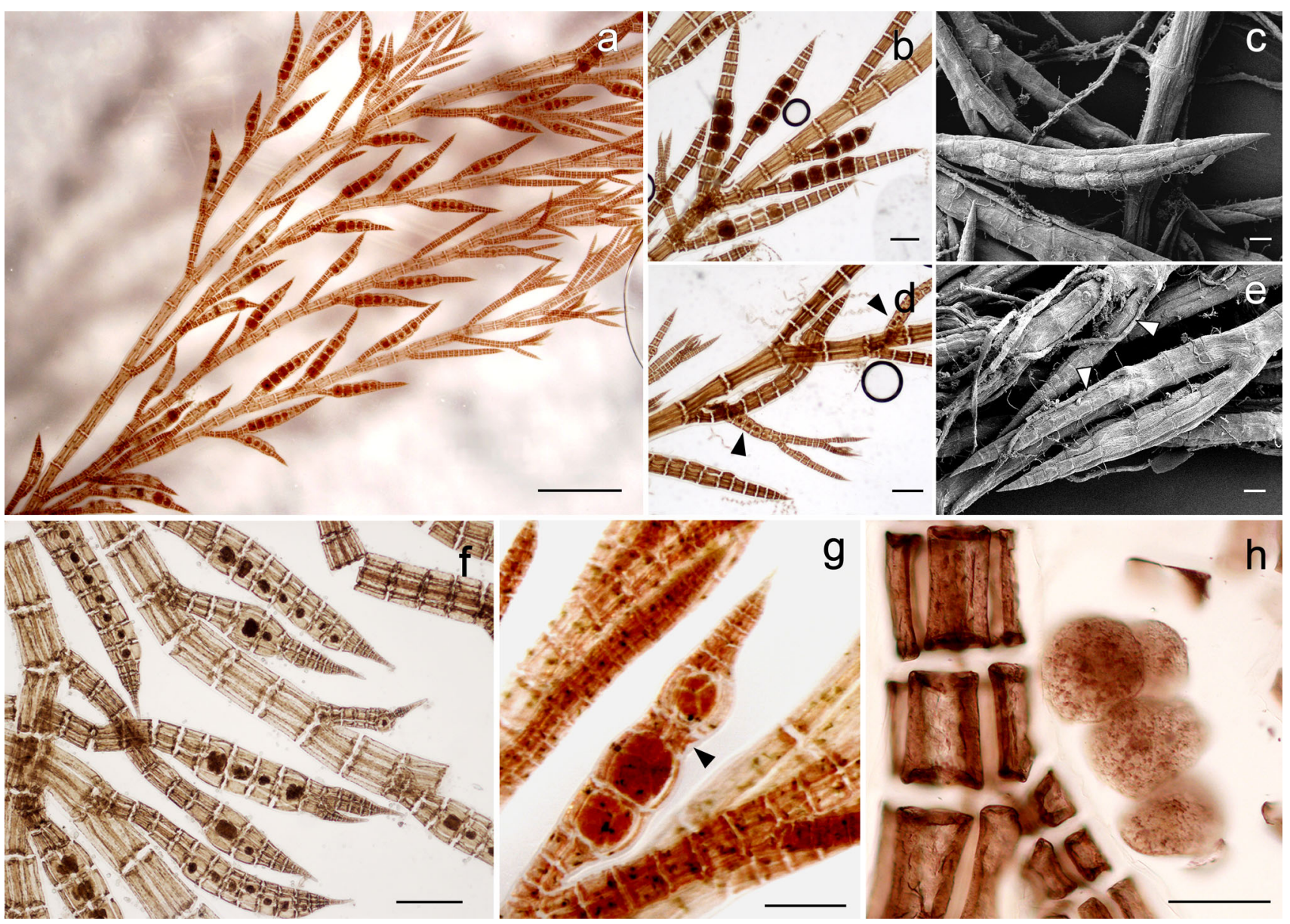

Fig. 4 Polysiphonia morrowii. Reproductive morphology of tetrasporophytes. a Aspect of the thallus; b determinate tetrasporangial branches; $\mathbf{c}$ detail of a determinate tetrasporangial branch in SEM; d endogenous axillary tetrasporangial branches bearing tetrasporangia (black arrowheads). Note the branching tip (white arrowhead). e detail of a tetrasporangial branch showing sharply pointed apices; white arrowheads denote trichoblasts; f tetrasporangial series of different lengths; $\mathbf{g}$ arrangement of mature tetrasporangia; arrowhead denotes a non-fertile segment; $\mathbf{h}$ shape of released tetraspores. Scale bars $\mathbf{a}=0.5 \mathrm{~mm} ; \mathbf{b}, \mathbf{d}, \mathbf{f}, \mathbf{g}$ and $\mathbf{h}=100 \mu \mathrm{m} ; \mathbf{c}$ and $\mathbf{e}=30 \mu \mathrm{m}$ branches, while others presented endogenous axillary branches that had tetrasporangia when fertile (Fig. 3g, h).

Fertile tetrasporophytes were found in every month. Tetrasporangia were mostly located in determinate short branches that were distributed throughout the thalli but were more abundant near the apices (Fig. $4 a-c)$. Some specimens presented one to three endogenous axillary branches bearing tetrasporangia (Fig. 4d). Endogenous axillary branches were observed in September and October only in tetrasporic thalli. Some tetrasporangial branches were determinate, while others were branched at the tip. They had sharply pointed apices and pyramidal apical cells (Fig. 4e, f). Tetrasporangia were arranged in straight series with 1-9 fertile segments and were sometimes interspersed with non-fertile segments (Fig. 4f). One tetrasporangium developed per segment. Fertile segments became enlarged when tetrasporangia were mature and expanded laterally. Tetrasporangial segmentation was tetrahedral. Tetraspores measured from 90 to $110 \mu \mathrm{m}$ in width (Fig. $4 \mathrm{~g}$ ) and were discoid (Fig. 4h).

Fertile female gametophytes were found in different stages of maturation (Fig. 5a-c). Young specimens presented procarps with a developed trichogyne protruding from them (Fig. 5d). Young cystocarps were surmounted by a slender forked trichoblast (Fig. 5e). Mature cystocarps were located laterally on erect axes and branches, supported by one cell stalk (Fig. 5f). Mature cystocarps were markedly urceolate (Fig. $5 \mathrm{~g}, \mathrm{~h}$ ), with a narrow neck and a wide ostiole (Fig. 5i) and measured $270-655 \mu \mathrm{m}$ in length and $200-590 \mu \mathrm{m}$ in width. Carpospores were clavate, measuring from 104 to $107 \mu \mathrm{m}$ in length (Fig. 5j).

Tetrasporophytes were more frequent than carposporophytes, whereas fertile male gametophytes were not recognized during the sampling period. The specimens were highly developed during the colder months and declined 

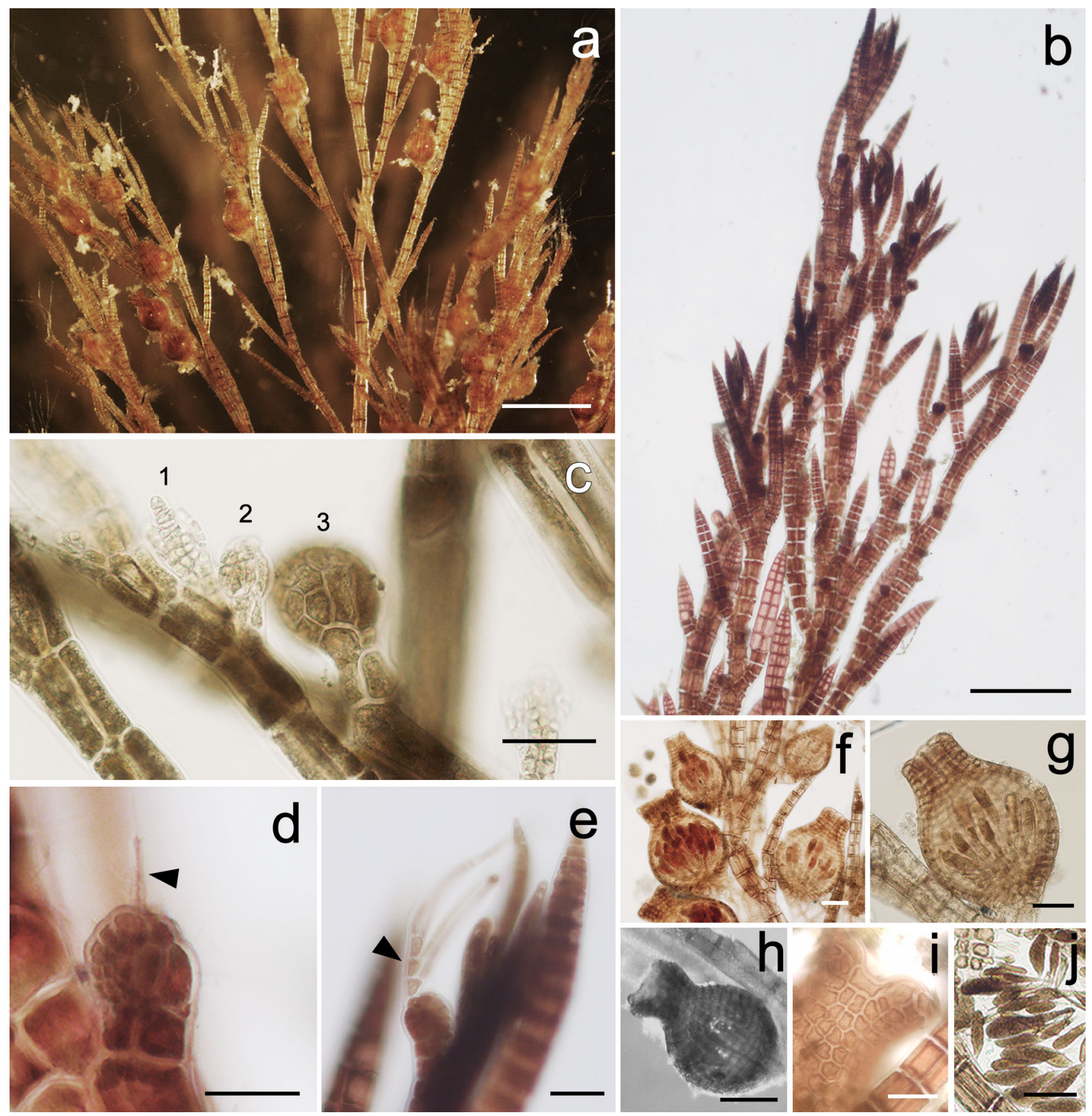

Fig. 5 Polysiphonia morrowii. Reproductive morphology of carposporophytes. a Aspect of a mature thallus; $\mathbf{b}$ aspect of an immature thallus; c progressive stages of maturation of cystocarps from 1 to 3 ; d detail of a trichogyne protruding from an immature cystocarp (arrowhead); e detail of a cystocarp surmounted by a forked hair

toward the warmer season, when they became epiphytized by diatoms and the filaments entangled with the sediment.

The population was present throughout the year, except from December to February when macroscopic thalli were not found. There were significant differences in the seasonal biomass $(p<<0.01 ; F=6.9$; $\mathrm{df}=71$ ) (Fig. 6). Maximum (arrowhead); f mature cystocarps; $\mathbf{g}$ urceolate shape of a mature cystocarp; $\mathbf{h}$ surface view of a mature cystocarp; $\mathbf{i}$ detail of the narrow neck and wide ostiole of a mature cystocarp; $\mathbf{j}$ shape of released carpospores. Scale bars $\mathbf{a}=1 \mathrm{~mm} ; \mathbf{b}=250 \mu \mathrm{m} ; \mathbf{c}, \mathbf{f}, \mathbf{g}, \mathbf{i}$ and $\mathbf{j}=100 \mu \mathrm{m} ; \mathbf{d}$ and $\mathbf{e}=50 \mu \mathrm{m} ; \mathbf{h}=200 \mu \mathrm{m}$

DW was found in winter, and minimum DW was found in spring. No significant differences were found between autumn and winter biomass $(p=0.48 ; t=0.03$; df $=17)$, neither between spring and summer biomass $(p=0.07 ; t=-1.6$; $\mathrm{df}=17)$. The WW/DW ratio was significantly higher in summer than in spring $(p<<0.01 ; t=-3.32 ; \mathrm{df}=17)$. 


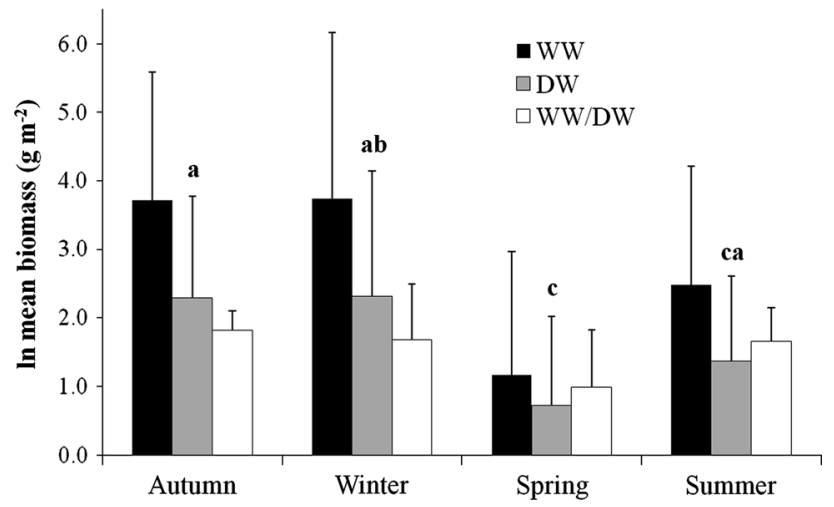

Fig. 6 Seasonal biomass of Polysiphonia morrowii. Letters above the bars indicate results of Fisher's pairwise comparisons. Biomass data were $(\ln +1)$ transformed. $W W$ wet weight, $D W$ dried weight

\section{Discussion}

Polysiphonia morrowii was first described by Harvey (1857) from specimens collected in Japan, as densely tufted thalli with setaceous texture, measuring up to $25 \mathrm{~cm}$ long and having subcorymbose apices. There were subsequent descriptions of specimens collected in Korea and Japan (Yoon 1986; Kudo and Masuda 1992; Kim et al. 1994), and further of specimens introduced in Italy, Chile, Turkey, France and New Zealand (Curiel et al. 2002; Kim et al. 2004; Erduğan et al. 2009; D’Archino et al. 2012; Geoffroy et al. 2012). The present study provides previously unpublished information on the vegetative and reproductive characters of $P$. morrowii from the South Atlantic Ocean.

There is some discrepancy about the morphological features used to diagnose P. morrowii. Kudo and Masuda (1981) mentioned the following diagnostic features: (a) the presence of primary axes and many secondary axes with indeterminate branches and stolons; (b) ecortication and 4 pericentral cells; (c) thickness of upright axes and setaceous texture; (d) ultimate branches sharply pointed; (e) endogenous axillary branches; (f) scarcity of trichoblasts; (g) straight lines of tetrasporangia on ultimate branches and on axillary branches; (h) axillary tetrasporangial branches in tufts of 7 or 8 ; (i) spermatangia replacing trichoblasts; and (j) urceolate cystocarps. All the characteristics observed in the present study were consistent with the majority of the descriptions of $P$. morrowii, but the most conspicuous features included the sharply pointed apices of branches and the presence of endogenous axillary branches bearing tetrasporangia in fertile thalli. Table 1 compares specimens of $P$. morrowii from the native habitat with specimens introduced in other locations, including the specimens found in the South Atlantic Ocean.

Length of thalli was similar to all descriptions of $P$. morrowii except those from the Mediterranean Sea and

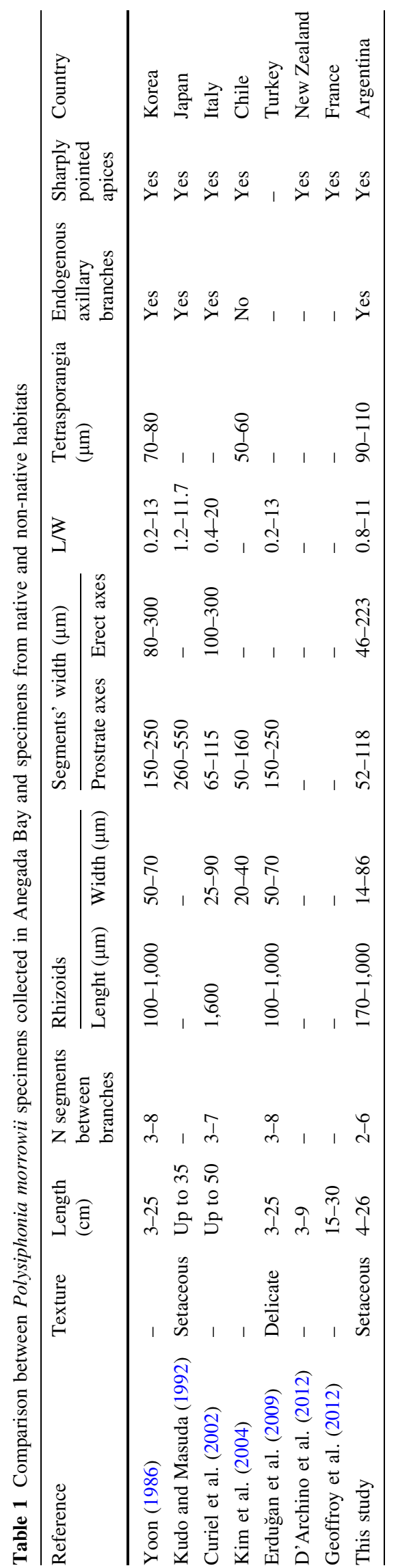


New Zealand (Curiel et al. 2002; D'Archino et al. 2012). Specimens described by Curiel et al. (2002) from the Mediterranean Sea were considerably larger than Japanese and Korean ones; however, some authors have emphasized on the monthly variability of thalli length (Lee and Lee 1991; Kim et al. 1994).

Polysiphonia morrowii thalli have been recently found in Punta Arenas, southern Chile, and their morphology was similar to that of specimens from Korea and Japan, except for the absence of axillary tetrasporangial branches, attributed to an early stage in the development of the thalli (Kim et al. 2004). This feature was present in the specimens collected in Anegada Bay; therefore, they represent the first record for South America of a Polysiphonia species bearing both endogenous axillary branches and axillary tetrasporangial branches. Kim et al. (2004) denoted a difference between Chilean and Korean/Japanese specimens in being more delicate, soft and abundantly branched. These features were also observed in the specimens collected in Anegada Bay; however, thalli were not delicate but had a setaceous texture as described by Kudo and Masuda (1992) for the Japanese ones.

Eleven species of Polysiphonia have been recorded for the Atlantic Patagonian coasts: P. abscissa, P. anisogona J.D. Hooker and Harvey, Neosiphonia harveyi (J.W. Bailey) M.S. Kim, H.G. Choi, Guiry and G.W. Saunders (as $P$. argentinica W.R. Taylor), P. nigra (Hudson) Batters (as $P$. atrorubescens Dillwyn (Greville), P. brodiei, P. cancellata Harvey, P. corymbifera (C. Agardh) Endlicher, P. fuscorubens J.D. Hooker and Harvey, P. hassleri W.R. Taylor, $P$. tenuistriata J.D. Hooker and Harvey and $P$. urceolata (Pujals 1963). Only a few of these species have been studied, and descriptions are scarce (Lazo 1982; Boraso et al. 2004).

On the basis of vegetative features, $P$. morrowii groups with other Atlantic and Pacific species such as P. stricta, $P$. atlántica, $P$. pacifica, $P$. pungens, $P$. scopulorum, $P$. senticulosa, $P$. subtilissima, $N$. harveyi and $P$. abscissa. Given some similarities between $P$. morrowii and the last two species (four pericentral cells, presence of trichoblasts, conspicuous scar cells, urceolate cystocarps) and according to earlier records of these two species along the Patagonian coast, previous specimens collected in Anegada Bay were misidentified and recorded as $P$. argentinica (currently considered a synonym of $N$. harveyi) and $P$. abscissa (Borges et al. 2005; Croce and Parodi 2012). However, the specimens studied differed in several features from $P$. abscissa such as the thickness of thalli, which is thicker in $P$. morrowii; the $\mathrm{L} / \mathrm{W}$ ratio, which is higher in $P$. morrowii; the branching pattern, which is subalternate in $P$. abscissa and alternate in $P$. morrowii; the number of segments between branches, which is higher in P. abscissa; the cystocarp shape, which is ovate in $P$. abscissa and urceolate in $P$. morrowii; and the apical cells, which are rounded in $P$. abscissa, while they are acute and spinose in P. morrowii (Yoon 1986). In addition, the specimens analyzed by us were clearly different from $N$. harveyi $(=P$. argentinica) in several features such as cortication, which is present in $N$. harveyi and absent in $P$. morrowii; the arrangement of tetrasporangia, which is spiral in $N$. harveyi and straight in $P$. morrowii; the connection between the rhizoid and the pericentral cell, which is open in $P$. morrowii and cut off in N. harveyi; and the presence of trichoblasts, which are abundant in $N$. harveyi while scarce in P. morrowii.

Phenological studies of $P$. morrowii mention higher occurrence of vegetative and tetrasporic thalli than fertile male and female thalli (Kim et al. 1994; Curiel et al. 2002; Geoffroy et al. 2012), and only a few studies have recorded all life history stages (Yoon 1986; Kudo and Masuda 1992; Kim et al. 1994; Curiel et al. 2002; Erduğan et al. 2009). Others even mention the absence of fertile gametophytes (Kim et al. 2004; Geoffroy et al. 2012). Kim et al. (1994) found that all reproductive stages of $P$. morrowii from Korea are present in the same period of time and that the life cycle is complete after 4 months. That was not the case in Anegada Bay, where almost all specimens observed in the present study were tetrasporophytes, and fertile female gametophytes were occasionally found, whereas male thalli were not registered. According to other studies, male thalli of $P$. morrowii are less frequent than tetrasporic and cystocarpic ones, appearing only in 1 month along the year (Kim et al. 1994). The presence of carposporophytes in Anegada Bay proves that sexual reproduction occurred, and thus, spermatangia were likely rapidly deciduous. The same trend has been often observed in many populations of $P$. morrowii located in different locations all over the world, as well as other species of red algae (Guiry and Womersley 1992; Kim et al. 1994; Curiel et al. 2002; Prathep et al. 2009; D'Archino et al. 2012). Unlike other studies of $P$. morrowii, mix-phases and simultaneous occurrence of different life history stages (Lawson and Russell 1967; Lee and Lee 1991; Curiel et al. 2002; Aguilar-Rosas et al. 2006) were not observed in the specimens collected in Anegada Bay. Several authors have denoted the ability of $P$. morrowii to colonize a variety of substrata and its rapid growth and vegetative propagation (Kudo and Masuda 1992; Kim et al. 1994, 2004).

In oyster reefs at Patagonia, the biomass of macroscopic thalli of $P$. morrowii increases in autumn and winter. The same trend has been registered in the Mediterranean Sea, Korea and France, where macroscopic thalli appear in early autumn, become covered by epiphytic algae in spring and decay in summer (Curiel et al. 2002; Geoffroy et al. 2012; Kim et al. 1994). The fact that macroscopic thalli were not found during a few months in Anegada Bay does not mean 
that the species is absent, and on the contrary, it is likely that prostrate axes remain attached to the substrate, from which new growth may occur each year.

The low abundance in spring is unexpected compared to the worldwide pattern of macroalgal seasonality; however, after 3 years of surveying the population, it was evident that the population decays as the water temperature increases in late spring and summer. An increase in biomass during the months of lower water temperature was expected, given that $P$. morrowii is characteristic of cold/ temperate waters (Kudo and Masuda 1992; Kim et al. 1994; Curiel et al. 2002). Polysiphonia morrowii is native to the North Pacific and survives temperatures between 6 and $25^{\circ} \mathrm{C}$ (Curiel et al. 2002; D'Archino et al. 2012). The temperature range in Anegada Bay goes from 5.6 to $24.8^{\circ} \mathrm{C}$; therefore, the species should be adapted to this particular habitat.

The WW/DW ratio was almost constant in autumn, winter and summer, but it was lower in spring. In spring, the thalli appeared epiphytized by diatoms in long and dense mucous colonies which were sometimes virtually impossible to eliminate; therefore, spring DW is somehow overestimated, which explains the lower WW/DW ratio.

This study confirms the broad distribution of this invasive Polysiphonia species and facilitates the comparison of distant populations. Several Polysiphonia species have been frequently recorded in oyster reefs or associated with oyster ponds and mainly to the pacific oyster $C$. gigas (Connor 1980; Hoagland 1982; Kamara 1982; Maggs and Stegenga 1999; Mineur et al. 2007). Exotic Polysiphonia species, such as $P$. setacea (currently regarded as a taxonomic synonym of Womersleyella setacea) have been also recorded in monospecific stands (Rindi et al. 1999). The specific dense occurrence of $P$. morrowii in the pools at Anegada Bay also resulted from $C$. gigas establishment, in addition to the fact that there are no other records of this species along the Atlantic Patagonian coast (Pujals 1963; Mendoza and Nizovoy 2000). This could suggest a simultaneous introduction of both Pacific species. If that was the case, Anegada Bay would probably be the first point of introduction of the species in Argentina, because the oysters were initially transplanted to this coast; however, it is likely to spread into other locations as a result of hatchery trials (Orensanz et al. 2002). It is important to notice that floristic studies are currently carried out by our research team in several locations along the Atlantic Patagonian coast from $38^{\circ} \mathrm{S}$ to $45^{\circ} \mathrm{S}$, and to date, P. morrowii has not been registered outside the bay.

Economic activities in the Anegada Bay region are scarce and include oyster exploitation and sport fishing carried out in small boats. Oyster aquaculture is no longer practiced in the region; however, the reefs are exploited by the local people as an economic resource as well as a management practice. Although fouling is considered as one of the most important sources of the introduction of exotic macroalgae (Haydar and Wolff 2011), it is unlikely that this vector is the source of $P$. morrowii introduction into Anegada Bay: the oceanographic conditions are unfavorable for industrial fishing vessels to enter the bay, and therefore, there is no harbor (Cuadrado and Gomez 2010).

Only three non-native macroalgal species have been previously recorded for the Atlantic Patagonian coast: Undaria pinnatifida (Harvey) Suringar, native to the Northwest Pacific Ocean (Casas and Piriz 1996; Casas et al. 2004; Martin and Cuevas 2006; Meretta et al. 2012), Sporochnus pedunculatus (Boraso and Negri 1997) and Anotrichium furcellatum (J. Agardh) Baldock (Boraso de Zaixso and Akselman 2005). The present study constitutes the fourth record of a non-native macroalgal species for the Atlantic Patagonian coast and the first record of an invasive Polysiphonia species. Kim et al. (2004) have suggested $U$. pinnatifida as a possible vector of $P$. morrowii in Chilean coasts, although $U$. pinnatifida has not been found in Chilean waters. On the contrary, U. pinnatifida has been introduced in Argentina, and there are known established populations. However, U. pinnatifida has never been recorded in Anegada Bay to date. Red algae are the largest taxonomic group introduced by oyster vectors, and $45 \%$ of the associated introductions originate from the Northwest Pacific (Haydar and Wolff 2011); hence, it is reasonable to consider the pacific oyster as a vector for the introduction of $P$. morrowii into the Atlantic Patagonian coasts. Although P. morrowii has been registered in Punta Arenas, Chile, we consider it very unlikely that the Chilean population could be the source of the Argentinean population, since the two coasts are located in different oceans about $1,800 \mathrm{~km}$ distant and separated by large latitude range. Even if that was the case, there are no clues to suggest a possible vector because vessel traffic between both coasts is not known; neither oyster transfers have been confirmed. In this context, it is more parsimonious to hypothesize a simultaneous introduction "oyster-algae."

As denoted by D'Archino et al. (2012), P. morrowii has been short listed as one of the 100 worst invasive species in the Mediterranean, and it is supposed to cause changes in biodiversity and problems in fisheries by clogging fishing nets (Streftaris and Zanetos 2006). The same phenomenon has been observed in Anegada Bay (Molina J.M., 2012, Universidad Nacional del Sur, pers. comm.) and denotes the imperative need for management since fishing is the primary economic activity in this region.

Given the recent establishment of $C$. gigas reefs in Anegada Bay, little is known about its interaction with the native benthic organisms (Escapa et al. 2004) and no associated exotic species have been reported to date. This 
study represents the first record of an alien species that is possibly related to the introduction of the Pacific oyster, to be found in Anegada Bay.

Negative interactions between exotic macroalgae and the native organisms have already been reported in Patagonia (Casas et al. 2004); hence, the impact of the invasive macroalga $P$. morrowii on this native ecosystem needs to be considered and evaluated. Further evaluation of the phylogenetic relationship between these specimens and those introduced in other localities would be of great relevance in order to determine the origin of the introduction and the relationship with other populations.

Acknowledgments This study was part of a $\mathrm{PhD}$ thesis project carried out by M.E. Croce, National Research Council (CONICET) Fellow. The Secretary of Science and Technology of the Universidad Nacional del Sur and CONICET provided funds, via grants PGI CSU24 B/145 and PIP 11220100100503, to E.R. Parodi, CONICET researcher.

\section{References}

Adams N (1991) The New Zealand species of Polysiphonia Greville (Rhodophyta). New Zeal J Bot 29:411-427

Aguilar-Rosas R, Aguilar-Rosas LE, Pedroche F (2006) Descripción de talos espermatangiales y combinación de fases en Polysiphonia confusa (Rhodomelaceae, Rhodophycota). Rev Mex Biodiv $77: 1-6$

Boraso de Zaixso AL, Akselman R (2005) Anotrichium furcellatum (Ceramiaceae, Rhodophyta) en Argentina. Una posible especie invasora. Bol Soc Argent Bot 40:207-213

Boraso AL, Negri R (1997) Presencia de Sporochnus pedunculatus (Sporochnales, Phaeophycophyta) en la costa Argentina. Physis Sec A 53:124-125

Boraso AL, Rico AE, Perales S, Pérez L, Zalazar H (2004) Algas marinas de la Patagonia, una guía ilustrada. Buenos Aires

Borges ME (2006) Ecología de las ostras en ambientes del sur bonaerense: cultivo y manejo de sus poblaciones. Dissertation, Universidad Nacional del Sur

Borges ME, Parodi ER, dos Santos EP (2005) Influencia de la comunidad incrustante (fouling) en la obtención de semillas de ostras sobre colectores, en Bahía Anegada. In: Vaquero MC, Cernadas de Bulnes MN (ed) Producción, recursos y medioambiente en el sudoeste bonaerense. EdiUNS, Bahía Blanca, pp 55-64

Casas GN, Piriz ML (1996) Surveys of Undaria pinnatifida (Laminariales, Phaeophyta) in Golfo Nuevo Argentina. Hydrobiologia 326(327):213-215

Casas G, Scrosati R, Piriz ML (2004) The invasive kelp Undaria pinnatifida (Phaeophyceae, Laminariales) reduces native seaweed diversity in Nuevo Gulf (Patagonia, Argentina). Biol Inv 6:411-416

Choi HG, Kim MS, Guiry MD, Saunders GW (2001) Phylogenetic relationships of Polysiphonia (Rhodomelaceae, Rhodophyta) and its relatives based on anatomical and nuclear small-subunit rDNA sequence data. Can J Bot 79:1465-1476

Connor JL (1980) Distribution and seasonality of macroalgae on oyster communities of central Chesapeake Bay. Bot Mar 23:711-717

Croce ME, Parodi ER (2012) Seasonal dynamic of macroalgae in intertidal pools formed by reefs of Crassostrea gigas (Mollusca,
Bivalvia) on the north Patagonian Atlantic coast. Bot Mar 55:49-58

Cuadrado DG, Gomez EA (2010) Geomorfología y dinámica del canal San Blas, provincial de Buenos Aires (Argentina). Latin Am J Sedimentol Basin Anal 17:3-16

Curiel D, Bellemo G, La Rocca B, Scattolin M, Marzocchi M (2002) First report of Polysiphonia morrowii Harvey (Ceramiales, Rhodophyta) in the Mediterranean Sea. Bot Mar 45:66-70

D'Archino R, Neill KF, Nelson WA (2012) Recognition and distribution of Polysiphonia morrowii (Rhodomelaceae, Rhodophyta) in New Zealand. Bot Mar 56:111-118

Eno NC (1996) Non-native marine species in British waters: effects and control. Aqu Cons Mar Fresh Ecosys 6:215-228

Erduğan H, Aki C, Acar O, Dural B, Aysel V (2009) New record for the East Mediterranean, Dardanelles (Turkey) and its distribution: Polysiphonia morrowii Harvey (Ceramiales, Rhodophyta). Turk J Fish Aquat Sc 9:231-232

Escapa M, Isacch JP, Daleo P et al (2004) The distribution and ecological effects of the introduced Pacific oyster Crassostrea gigas (Thunberg, 1793) in Northern Patagonia. J Shellfish Res 23:765-772

Fralick RA, Mathieson AC (1975) Physiological ecology of four Polysiphonia species (Rhodophyta, Ceramiales). Mar Biol 29:29-36

Gardner NL (1927) New Rhodophyceae from the Pacific coast of North America. VI. Univ Calif Publ Bot 14:99-138

Geoffroy A, Le Gall L, Destombe C (2012) Cryptic introduction of the red alga Polysiphonia morrowii Harvey (Rhodomelaceae, Rhodophyta) in the North Atlantic Ocean highlighted by DNA barcoding approach. Aquat Bot 100:67-71

Gruet Y (1976) Présence de l'algue japonaise Sargassum muticum (Yendo) Fensholt sur la côte française de Normandie. Bull Soc Sci Nat Ouest Fr 74:101-104

Guiry MD, Womersley HBS (1992) Gelidiella minima sp. nov. (Rhodophyta) from Victoria, Australia: implications for the generic classification of the Gelidiaceae. Br Phycol J 27: $165-176$

Harvey WH (1857) Algae. Account of the botanical specimens. In: Gray A (ed) Narrative of the expedition of an American squadron to the China Seas and Japan, performed in the years 1852, 1853 and 1854, under the command of Commodore M.C. Perry, United States Navy. Volume II. Senate of the Thirty-third Congress, Second Session, Executive Document House of Representatives, Washington, pp 331-332

Haydar D, Wolff WJ (2011) Predicting invasion patterns in coastal ecosystems: relationship between vector strength and vector tempo. Mar Ecol Prog Ser 431:1-10

Hoagland KE (1982) Ecological studies of wood-boring bivalves in the vicinity of the oyster creek nuclear generating station. Nureg/ CR-27272

Hollenberg GJ, Norris JN (1977) The red alga Polysiphonia (Rhodomelaceae) in the Northern Gulf of California. Smithsonian Institution Press, Washington

Kamara AB (1982) Preliminary studies to culture mangrove oysters, Crassostrea tulipa, in Sierra Leone. Aquaculture 27:285-294

Kapraun DF, Rueness J (1983) The genus Polysiphonia (Ceramiales, Rhodomelaceae) in Scandinavia. Gior Bot Ital 117:1-30

Kapraun DF, Searles RB (1990) Planktonic bloom of an introduced species of Polysiphonia (Ceramiales, Rhodophyta) along the coast of North Carolina, USA. Hydrobiologia 204-205:269-274

Kim MS (2003) Taxonomic reassessment of the genus Polysiphonia (Rhodomelaceae, Rhodophyta): morphology and reproduction of Neosiphonia decumbens and N. harlandii. Algae 18:107-109

Kim MS, Abbot IA (2006) Taxonomic notes on Hawaiian Polysiphonia, with transfer to Neosiphonia (Rhodomelaceae, Rhodophyta). Phycol Res 54:32-39 
Kim MS, Lee IK, Boo SM (1994) Morphological studies of the red alga Polysiphonia morrowii Harvey on the Korean coast. Korean J Phycol 9:185-192

Kim MS, Maggs CA, McIvor L, Guiry MD (2000) Reappraisal of the type species of Polysiphonia (Rhodomelaceae, Rhodophyta). Eur J Phycol 35:83-92

Kim MS, Yang EC, Mansilla A, Boo SM (2004) Recent introduction of Polysiphonia morrowii (Ceramiales, Rhodophyta) to Punta Arenas, Chile. Bot Mar 47:389-394

Kudo T, Masuda M (1981) A taxonomic study of Polysiphonia morrowii Harvey (Rhodophyta, Ceramiales). Jap J Phycol 29:263-272

Kudo T, Masuda M (1992) Taxonomic features of Polysiphonia morrowii Harvey (Ceramiales, Rhodophyta). Korean J Phycol 7:13-26

Lawson RP, Russell G (1967) Simultaneous occurrence of carposporophytes and tetrasporangia in Polysiphonia urceolata. $\mathrm{Br}$ Phycol Bull 3:249-250

Lazo ML (1982) Novedades en Rhodophyta Argentinas. Bol Soc Argent Bot 21:65-80

Lee WJ, Lee IK (1991) Mixed phases reproduction of Polysiphonia morrowii Harvey (Rhodomelaceae, Rhodophyta) in culture. Jap J Phycol 39:115-121

Lining T, Garbary DJ (1992) The Ascophyllum/Polysiphonia/Mycosphaerella Symbiosis. III. Experimental studies on the interactions between P. lanosa and A. nodosum. Bot Mar 35:341-349

Lobban CS, Baxter DM (1983) Distribution of the red algal epiphyte Polysiphonia lanosa on its brown algal host Ascophyllum nodosum in the Bay of Fundy, Canada. Bot Mar 26:533-538

Maggs CA, Stegenga H (1999) Red algal exotics on North Sea coasts. Helgo Meeres 52:243-258

Martin JP, Cuevas JM (2006) First record of Undaria pinnatifida (Laminariales, Phaeophyta) in Southern Patagonia, Argentina. Biol Inv 8:1399-1402

McIvor L, Maggs CA, Provan J, Stanhope MJ (2001) rbcL sequences reveal multiple cryptic introductions of the Japanese red alga Polysiphonia harveyi. Mol Ecol 10:911-919

Mendoza ML, Nizovoy A (2000) Géneros de macroalgas marinas de la Argentina fundamentalmente de Tierra del Fuego. Poder legislativo de la provincia de Tierra del Fuego, Tierra del Fuego

Meñez EG (1964) The taxonomy of Polysiphonia in Hawaii. Pac Sci 18:207-222

Meretta PE, Matula CV, Casas G (2012) Occurrence of the alien kelp Undaria pinnatifida (Laminariales, Phaeophyceae) in Mar del Plata, Argentina. BioInvasions Rec 1:59-63

Mineur F, Belsher T, Johnson MP, Maggs CA, Verlaque M (2007) Experimental assessment of oyster transfers as a vector for macroalgal introductions. Biol Cons 137:237-247
Orensanz JM, Schwindt E, Pastorino G et al (2002) No longer the pristine confines of the world ocean: a survey of exotic marine species in the southwestern Atlantic. Biol Inv 4:115-143

Prathep A, Lewmanomont K, Buapet P (2009) Effects of wave exposure on population and reproductive phenology of an algal turf, Gelidium pusillum (Gelidiales, Rhodophyta), Songkhla, Thailand. Aq Bot 90:179-183

Pujals C (1963) Catalogo de Rhodophyta citadas para la Argentina. Museo Argentino de Ciencias Naturales e Instituto Nacional de Investigación de las Ciencias Naturales Buenos Aires, Buenos Aires

R Development Core Team (2012) R: A language and environment for statistical computing. R Foundation for Statistical Computing, Vienna, Austria. ISBN 3-900051-07-0, URL http://www.Rproject.org/. Accessed March 2012

Rindi F, Guiry MD, Cinelli F (1999) Morphology and reproduction of the adventives Mediterranean rhodophyte Polysiphonia setacea. Hydrobiologia 398(399):91-100

Sliwa C, Migus S, McEnnulty F, Hayes KR (2009) Marine bioinvasions in Australia. Biological invasions in marine ecosystems. Ecol Stud 204:425-437

Spalleti L (1980) Paleoambientes sedimentarios en secuencias silicoclásticas. Asoc Geol Arg 8:1-175

Stegenga H, Mol I, Prud'Homme van Reine WF, Lokhorst GM (1997) Checklist of the marine algae of the Netherlands. Gorteria Supplement 4:1-57

Streftaris N, Zanetos A (2006) Alien marine species in the Mediterranean-the 100 'worst invasive' and their impact. Mediterr Marine Sci 7:87-118

Stuercke B, Freshwater DW (2008) Consistency of morphological characters used to delimit Polysiphonia sensu lato species (Ceramiales, Florideophyceae): analyses of North Carolina, USA specimens. Phycologia 47:541-559

Stuercke B, Freshwater DW (2010) Two new species of Polysiphonia (Ceramiales, Florideophyceae) from the western Atlantic. Bot Mar 53:301-311

Thomsen MS, McGlathery KJ, Tyler AC (2006) Macroalgal distribution patterns in a shallow, soft-bottom lagoon with emphasis on the nonnative Gracilaria vermiculophylla and Codium fragile. Estuar. Coasts 29:465-473

Verlaque M (1981) Contribution à la flore des algues marines de Méditerranée : espèces nouvelles pour la Méditerranée Occidentale. Bot Mar 24:559-568

Womerseley HBS (1979) Southern Australian species of Polysiphonia Greville (Rhodophyta). Aust J Bot 27:459-528

Yoon HY (1986) A taxonomic study of genus Polysiphonia (Rhodophyta) from Korea. Korean J Phycol 1:3-86 